\title{
MEMES DE NATUREZA CÔMICA COMO ESTRATÉGIA DE RESISTÊNCIA A DISCURSOS HEGEMÔNICOS: ANÁLISE DAS REAÇÕES À CAMPANHA \#GAYSNOMERECENMEDALLAS NO TWITTER
}

\author{
Thiago Dias Oliva* \\ Universidade de São Paulo \\ Faculdade de Direito \\ São Paulo, SP, Brasil
}

\begin{abstract}
Resumo: Em agosto de 2016, em meio aos Jogos Olímpicos do Rio de Janeiro, a hashtag \#GaysNoMerecenMedallas, ou Gays não merecem medalhas, tornou-se trending topic do Twitter. Este trabalho propõe a análise do uso do humor como estratégia para ressignificar termos, imagens e símbolos historicamente empregados na representação social negativa de LGBT para mostrar como a estratégia pode ser efetiva ao desarticular ataques a esse grupo social na internet, esvaziando-os de sentido por meio do riso. $O$ artigo propõe, como objetivo específico, a análise de cinco memes que foram postados em meio à campanha \#GaysNoMerecenMedallas, atacando a hashtag. Teoricamente, destacam-se as noções de ator social da Análise Crítica do Discurso, de poder e hegemonia em Teun van Dijk (2015), bem como os critérios para o estudo de discursos multimodais presentes em Nascimento, Bezerra e Heberle (2011). A metodologia segue o caminho estabelecido por Fairclough (2012).
\end{abstract}

Palavras-chave: LGBT. Ator social. Memes. Humor. Resistência.

\section{INTRODUÇÃO E METODOLOGIA}

O Twitter tem se destacado entre as plataformas de comunicação via internet, sobretudo, para a divulgação de informações de maneira rápida e com grande capilaridade. Isso se deve, em grande medida, a seu formato que conjuga limitação de 280 caracteres às mensagens - o que impõe ao usuário grande concisão na redação dos "tweets" (ou "tuítes") - e possibilidade de replicar tuítes postados por outros usuários os "retuítes". Outra funcionalidade da plataforma permite aos usuários organizar assuntos por meio de hashtags, facilitando a retomada de tópicos para discussão na rede social, inclusive a articulação de ações em torno de pautas específicas ou a simples reação de maneira orgânica - i.e., não necessariamente organizada - com a finalidade de atacar ou apoiar um determinado posicionamento ou ideia.

Em agosto de 2016, em meio aos Jogos Olímpicos do Rio de Janeiro, uma dessas hashtags tornou-se trending topic do Twitter, i.e., tornou-se um dos assuntos mais comentados na plataforma: \#GaysNoMerecenMedallas, ou "Gays não merecem

\footnotetext{
* Doutorando em Direito Internacional Público na Faculdade de Direito da Universidade de São Paulo. Mestre em Direitos Humanos pela mesma instituição. Coordenador de pesquisa na área de Liberdade de Expressão no InternetLab em São Paulo. E-mail: thiago.oliva@usp.br.
} 
medalhas", em português. A hashtag foi compartilhada mais de 14 mil vezes no Twitter ${ }^{1}$ no dia 11 de agosto, em meio à crescente visibilidade de atletas lésbicas, gays, transexuais e travestis (LGBTs) na "Olimpíada mais gay da história", conforme noticiado por alguns meios de comunicação (AVENDAÑO, 2016). Além de ter maior contingente de atletas LGBTs que se declararam como tal publicamente em comparação com edições anteriores, os Jogos Olímpicos do Rio produziram numerosas imagens de inclusão, a exemplo do pedido de casamento proposto por uma voluntária na organização dos jogos a uma atleta brasileira, após a final do rúgbi feminino, e da participação de transexuais na cerimônia de abertura.

Ainda que simbólica, ao menos no que diz respeito à efetiva participação dos LGBTs nos jogos - apenas 43 no universo de 11.237 atletas, ou cerca de $0,38 \%$ do total - a presença de lésbicas, gays, bissexuais e transexuais em um espaço tradicionalmente conhecido pela reprodução das normas de gênero pareceu incomodar. Nesse contexto, o surgimento da hashtag \#GaysNoMerecenMedallas apenas ilustra o quanto a vulnerabilidade de LGBTs permanece uma realidade, com indivíduos constantemente rejeitando a existência de pessoas que relativizam normas de gênero no espaço público.

Ao afirmar que "gays não merecem medalhas", o criador da hashtag transmite a mensagem de que ser LGBT não é motivo de orgulho (sentimento geralmente associado a medalhas), apoiando-se na ideologia do heterossexismo, ao reforçar a existência de hierarquia entre sexualidades, o que resulta na contínua exclusão dos integrantes desse grupo social, mesmo nos tempos da "Olimpíada mais gay da história".

$\mathrm{O}$ heterossexismo contribui de forma decisiva para o aumento da hostilidade frente a gays, lésbicas, bissexuais, transexuais e travestis, alimentando uma ordem social de exclusão e construindo a ideologia que se encontra por trás da permanente violação de direitos de LGBTs. Essa ideologia guarda relação de similitude com o antissemitismo, o racismo e o sexismo, pois estabelece uma hierarquia entre dois ou mais grupos de pessoas. Ao fazê-lo, sustenta a dominação de um grupo sobre os demais, marginalizando-os por meio de uma distribuição injusta de poder político e econômico (OLIVA, 2015).

Sob a ótica do heterossexismo, o sexo biológico, caracterizado pela carga genética e pela sua externalização física, e o "sexo social", relativo ao papel que cabe a cada um dos gêneros na sociedade, devem coincidir. Além disso, o desejo sexual só é socialmente aceitável quando surgir entre indivíduos de sexos opostos. Nesses termos, toda e qualquer outra forma de expressão da sexualidade e do gênero deve ser rejeitada (BORRILLO, 2010).

É em decorrência da prevalência dessa ideologia que os LGBTs permanecem sujeitos à violência e à exclusão, conforme evidenciam estatísticas do Grupo Gay da Bahia. Segundo o relatório publicado em janeiro de 2017 (GUATHIER, 2017; MOTT; MICHELS, 2017), no ano anterior, 343 LGBTs foram vítimas de homicídio motivado por ódio no país. Para o coordenador do relatório, Luiz Mott, os números são ainda maiores, já que a subnotificação dos crimes dessa ordem é significativa. Em 2012, também a então Secretaria de Direitos Humanos da Presidência da República, valendo-se de dados referentes às denúncias realizadas via "Disque Direitos Humanos", apresentou relatório

\footnotetext{
${ }^{1}$ Os números foram obtidos por meio da ferramenta "trends" do Observatory on Social Media e da busca por \#GaysNoMerecenMedallas entre os dias 10 e 28 de agosto de 2016. Para mais informações, cf.: $<$ http://osome.iuni.iu.edu/tools/trends/>.
} 
atestando os níveis alarmantes de violência contra LGBTs em território nacional. O documento reporta " 27,34 violações de direitos humanos de caráter homofóbico por dia" (BRASIL, 2013, p. 18).

Outro estudo, baseado em entrevistas realizadas com participantes da Parada do Orgulho LGBT na cidade do Rio de Janeiro, em 2012, assinala que 69,8\% deles já foram vítimas de discriminação em virtude da sua sexualidade, enquanto 63,9\% afirmaram já terem sofrido alguma forma de agressão pelo mesmo motivo (CARRARA et al., 2017, p. 72).

Ao situarmos a campanha \#GaysNoMerecenMedallas no contexto de violência e segregação dos LGBTs descrito acima, percebemos que ela reproduz discursos anteriores que negam a essas pessoas o direito de ocupar o espaço público. Em outras palavras, a campanha consiste em reprodução discursiva da dominação existente entre heterossexuais e homossexuais / cisgêneros e transexuais, nos termos colocados por van Dijk (2015).

O autor, ao empreender a análise do discurso por meio de uma perspectiva crítica, defende que o discurso das elites simbólicas, ao propagar ideologias segregacionistas que alicerçam a ordem social constituída, contribui de forma determinante para a reprodução dessa realidade, em que determinados grupos de pessoas encontram-se em posição desfavorável em virtude de suas características identitárias, tais como gênero (feminino), raça/etnia (negra ou indígena, no contexto brasileiro), orientação sexual (lésbica, gay, bissexual), identidade de gênero (transexual, travesti), dentre outras.

No entanto, simultaneamente à reprodução do discurso segregacionista que propõe o distanciamento entre o "eu" (branco, masculino, heterossexual, cisgênero) e o "outro" (negro, feminino, homossexual, transexual), bem como a desumanização dos grupos subalternizados, há a resistência por parte desses grupos. Partindo da perspectiva de "ator social" proposta pela Análise Crítica do Discurso, consideramos que o processo de interpelação ideológica não é determinante para o indivíduo, o qual pode agir conscientemente contra a reprodução da ordem social constituída - ainda que no nível do inconsciente tenda a acionar seus modelos mentais apoiados nas ideologias dominantes e replicar práticas que reforcem estruturas sociais preexistentes (MELO, 2009).

A resistência de grupos dominados ao poder exercido por grupos dominantes pode se dar de várias formas, inclusive por iniciativas de contradiscurso e disputas de narrativas, estratégias empregadas por ativistas ligados a causas de grupos subalternizados.

Nesse contexto, podemos situar as reações à campanha \#GaysNoMerecenMedallas como uma tentativa de reverter a ideia de que ser LGBT não é motivo de orgulho, expondo-a como intolerante e inaceitável. Dentre os inúmeros tuítes que atacaram a hashtag, destacaram-se aqueles que fizeram uso do humor - sobretudo por meio de "memes" - para expor ao ridículo os usuários que apoiaram a campanha LGBTfóbica.

Considerando a importância das disputas de narrativa como ferramenta para modificar uma ordem social que segue mantendo os LGBTs à margem da sociedade, este trabalho propõe-se a analisar justamente o uso do humor como estratégia para ressignificar termos, imagens e símbolos historicamente empregados na representação social negativa de LGBTs. Mais especificamente, o trabalho tem por objetivo investigar como o público LGBT mobiliza formas de fazer humor próprias do ambiente digital para 
construir um sentido positivo a expressões e imagens como "viado", "sapatão" e "Vale dos Homossexuais", bem como relativizar a autoridade de símbolos religiosos - como o Papa e a Bíblia. A ideia é mostrar como a estratégia pode ser efetiva ao desarticular ataques a LGBTs na internet, esvaziando-os de sentido por meio do riso.

Para empreender essa tarefa, far-se-á análise de cinco memes que foram postados em meio à campanha \#GaysNoMerecenMedallas no Twitter, atacando a hashtag. Como referencial teórico para o artigo, destacam-se as noções de "ator social" da Análise Crítica do Discurso, de poder e hegemonia conforme propostas por Teun van Dijk (2015), bem como os critérios para o estudo de discursos multimodais presentes em Multiletramentos: iniciação à análise de imagens de Nascimento, Bezerra e Heberle (2011, p. 529-552).

A metodologia orienta-se pelo caminho estabelecido por Fairclough em Análise crítica do discurso como método em pesquisa social científica (2012, p. 307-329): 1. Dar ênfase a problema social que tenha aspecto semiótico; 2. Identificar obstáculos para solução do problema, pela análise: a. Da rede de práticas no qual está inserido; b. Das relações de semiose com outros elementos dentro das práticas particulares em questão; c. Do discurso: i. Estrutura analítica: a ordem de discurso; ii. Análise interacional; iii. Análise interdiscursiva; iv. Análise linguística e semiótica; 3. Considerar se a ordem social (rede de práticas) em algum sentido é um problema ou não; 4. Identificar maneiras possíveis para superar obstáculos; 5 . Refletir criticamente sobre a análise (1 a 4).

Aplicando e adaptando a metodologia de Fairclough (2012) para a análise proposta, o trabalho começará (1) indicando a discriminação dos LGBTs como problema social com aspecto semiótico, tendo em vista a propagação da ideologia heterossexista por meio do discurso. A seguir, o trabalho (2) identificará quais são os obstáculos semióticos à superação da opressão aos LGBTs, (a) apontando a rede de práticas por trás da hierarquia de sexualidades; (b) destacando a articulação dos elementos semióticos com sociais; e (c) analisando a estrutura e aspectos interacionais, interdiscursivos e linguísticos de dois exemplos concretos de discursos LGBTfóbicos. Depois de (3) ponderar em que medida a rede de discursos LGBTfóbicos representa um problema, o trabalho (4) apontará estratégias utilizadas pelo grupo social em questão para desarticular essa rede de práticas. O enfoque do trabalho será justamente o passo (4), no âmbito do qual atos discursivos de resistência articulados por LGBTs serão analisados mais detidamente. Por fim, (5) o trabalho sistematizará as conclusões que se pode fazer a partir dessa análise, desenvolvendo reflexões críticas.

\section{LGBTS NA REDE: OPRESSÃO E RESISTÊNCIA}

Podemos considerar o discurso como processo linguístico que confere existência social às coisas, uma prática social. Como processo de caráter relacional, o discurso estrutura-se em torno da dicotomia "eu" (enunciador) X "outro" (enunciatário), polarização que é levada ao extremo no caso de discursos discriminatórios (BOLÍVAR, 2003): ao rearticular linguisticamente uma relação social de dominação e as estruturas que a conformam, o discurso desse tipo intimida membros de grupos subalternizados (exogrupo) e, simultaneamente, instiga o restante da sociedade a considerar essas pessoas como inferiores, muitas vezes desumanizando-as. Para tanto, relaciona alguma característica identitária do grupo social visado (tal qual gênero, raça/etnia, orientação 
sexual, etc.) a condutas ou atributos usualmente avaliados como negativos pela sociedade. Ao fazê-lo, traz à tona a rejeição latente, no tecido social, a uma determinada minoria, rejeição essa apoiada em ideologia de grupos hegemônicos que segue pautando novos discursos discriminatórios (VAN DIJK, 2015).

Essa rearticulação pressupõe ato discursivo anterior e gera consequências próprias, no que Butler (1997, p. 14) denomina "corrente de ressignificações": uma permanente produção e reatribuição de sentido a discursos anteriores, bem como a alteração do contexto linguístico em que serão produzidos novos discursos.

Partindo das reflexões de van Dijk em Discurso e Poder (2015), podemos conceber a manutenção da desigualdade material entre grupos sociais distintos como resultado de uma complexa interação entre estruturas sociais, discursivas e cognitivas, em que o contexto social - permeado por ideologias hegemônicas que refletem valores dos grupos dominantes - pauta a produção de discursos e de seus sentidos, o que, por sua vez, desenha modelos mentais em nível individual ${ }^{2}$. Esse é, em outras palavras, o mecanismo de reprodução do poder social que resulta na desigualdade: os grupos detentores do poder, apoiados em estruturas que mantiveram, ao longo do tempo, hierarquias sociais, dominam o discurso de instituições de relevância na esfera pública e fazem uso delas para colonizar mentes, formatando modelos cognitivos alinhados aos seus propósitos na manutenção dessas hierarquias ${ }^{3}$.

Mateus e Resende (2015, p. 454) destacam a dimensão histórica do fenômeno, no qual os atores sociais têm suas ações pautadas pelas ações de atores que os antecederam, os quais já haviam sido conformados, em suas ações, por estruturas sociais preexistentes, em um processo sem fim.

No caso específico dos LGBTs, o discurso LGBTfóbico replicou-se no âmbito de diferentes instituições, apoiado na ideologia heterossexista de origem, ao menos no Ocidente, no empreendimento de marginalização de condutas sexuais sem fins reprodutivos, discurso esse encampado pela Igreja na Idade Média ("pecado") e retomado pelas ciências médicas ("antinatural”) e humanas ("degenerescência”) no século XIX (OLIVA, 2015, p. 20-21). Pode-se, assim, concluir que a discriminação aos LGBTs, tal qual a discriminação dirigida a outros grupos sociais subalternizados, é dotada de elemento semiótico ${ }^{4}$.

Atualmente, o discurso LGBTfóbico segue sendo alimentado e retroalimentando o heterossexismo ${ }^{5}$ de modo a legitimar a limitação de liberdades e a violação de direitos das minorias sexuais. O discurso é, dessa forma, empregado como veículo linguístico para manter os LGBTs à margem da sociedade, sendo a presença e a difusão da sua versão

\footnotetext{
${ }^{2}$ Van Dijk considera, inclusive, que o exercício e a manutenção do poder social "pressupõem uma estrutura ideológica [...] formada por cognições fundamentais, socialmente compartilhadas e relacionadas aos interesses de um grupo e seus membros [...] [sendo] adquirida, confirmada ou alterada, principalmente, por meio da comunicação e do discurso" (2015, p. 43).

${ }^{3}$ Nas palavras de Van Dijk, "macroestruturas sociais são relacionadas com as estruturas do discurso público e, finalmente, como essas podem influenciar as mentes do público em geral”, "pessoas são influenciadas pelas notícias que leem ou veem [...] mas sua compreensão das notícias e a maneira como mudam suas opiniões ou atitudes dependem de suas próprias atitudes ou ideologias prévias [...] como também de suas experiências pessoais." (2015, p. 25).

${ }^{4}$ Ênfase a problema social com aspecto semiótico, primeira etapa da metodologia de Fairclough (2012).

${ }^{5}$ Para entender os mecanismos de controle que resultam na replicação do poder e na reprodução da desigualdade, conferir sobre gêneros de discurso: van Dijk, 2015, p. 52-53.
} 
LGBTfóbica no meio social, a única explicação para a preservação de uma ordem social de exclusão dessas minorias (BORILLO, 2010, p. 63-64), o que constitui verdadeiro obstáculo à construção de uma sociedade inclusiva e aberta à diversidade sexual ${ }^{6}$. Esse tipo de discurso tem impacto, inclusive, sobre a esfera de liberdade e a percepção que os LGBTs têm de si mesmos.

Nesse contexto, podemos situar a campanha \#GaysNoMerecenMedallas no Twitter como mais uma tentativa de reproduzir uma ordem social em que os LGBTs são marginalizados, negando a eles que ocupem espaços de protagonismo, a exemplo dos Jogos Olímpicos, competição esportiva de grande relevância para a comunidade internacional. A campanha, como será possível inferir da análise de duas postagens no Twitter a seguir, está inserida em uma rede mais ampla de discursos e práticas que visam afastar os LGBTs do espaço público.

O tuíte que deu início à polêmica (Figura 1) teria sido postado (LÓPEZ, 2016) por Daniel Bisogno, apresentador mexicano. Ele diz, traduzindo para o português, "tremenda falta de respeito que levantem uma bandeira gay durante as olimpíadas, façamos um $T^{7}$ \#GaysNãoMerecemMedalhas".

Figura 1 - Primeiro Tuíte com a hashtag \#GaysNãoMerecemMedalhas

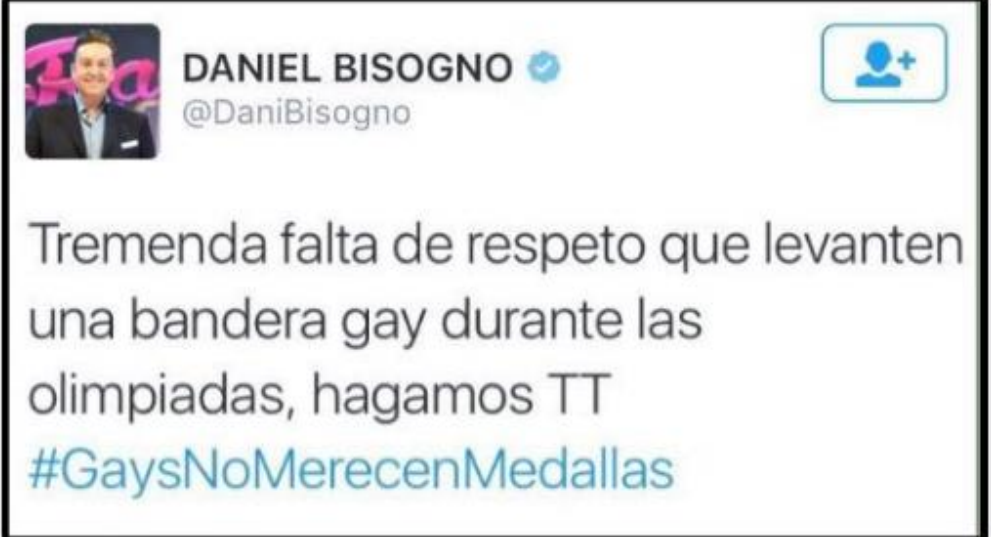

Fonte: Twitter, 2017

O uso da expressão "levantar bandeira" remete, figurativamente, ao sentido de difundir uma ideologia, encampar uma luta, afirmar um grupo no espaço público - ainda que a bandeira do arco-íris tenha sido possivelmente hasteada por espectadores em determinados eventos dos Jogos do Rio. Dessa forma, o autor do tuíte mostrou-se contrário à visibilidade crescente dos LGBTs na Olimpíada, o que, conforme mencionado na introdução do presente estudo, evidenciou-se pelas imagens de inclusão da "Olimpíada mais gay da história" e sua repercussão positiva na mídia e nas redes sociais. A ideia de que ostentar publicamente uma sexualidade ou identidade de gênero discordante da

\footnotetext{
${ }^{6}$ Identificação dos obstáculos para a superação do problema, segunda etapa da metodologia de Fairclough (2012), a ser desenvolvida a partir da análise de tuítes homofóbicos (Figuras 1 e 2).

7 "TT" é sigla para a expressão trending topic, do inglês, utilizada no contexto do Twitter para fazer referência às hashtags que mais foram compartilhadas na rede social em um determinado período de tempo. A intenção do autor do tuíte é difundir a hashtag \#GaysNãoMerecemMedalhas, chamando mais pessoas a se posicionarem contra a expressão da diversidade sexual nos Jogos do Rio.
} 
norma seria uma "falta de respeito", isto é, algo moralmente condenável, transmite justamente a mensagem de que os LGBTs devem "voltar para o armário", já que a sexualidade seria uma questão privada e eventuais "desvios" devem permanecer à margem da sociedade, na invisibilidade.

Essa ideia é reforçada pela hashtag "gays não merecem medalhas", em que o autor do tuíte transmite a mensagem de que ser LGBT não deve ser motivo de orgulho principal emoção daquele que recebe uma medalha nos Jogos Olímpicos - o que dialoga com (e nega) a própria noção de "orgulho LGBT" como topos, base sobre a qual o movimento LGBT articula estratégias de visibilidade no espaço público (como as "Paradas do Orgulho LGBT").

Ao chamar outros usuários do Twitter a fazer da hashtag um trending topic, o responsável pela campanha LGBTfóbica transmite uma mensagem também ao público em geral para que se junte a ele no repúdio à presença de LGBTs no espaço público. É, assim, uma estratégia de reprodução do discurso que visa, em última instância, a replicar a ideologia do heterossexismo, mantendo viva a hierarquia entre sexualidades.

Sobretudo em uma plataforma como o Twitter, em que informações circulam com grande rapidez e de forma organizada, esse tipo de mensagem serve de ponto focal para novas manifestações discriminatórias - de cunho inclusive muito mais agressivo que o tuíte original, a exemplo da postagem que consta da Figura 2: "Os gays não merecem

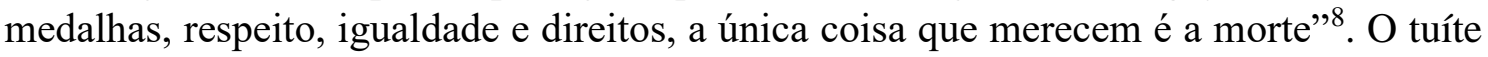
é acompanhado, ainda, por uma imagem que mostra uma pessoa segurando cartaz em que se lê "prefiro um filho morto que um maricas" .

\section{Figura 2 - Tuíte com discurso de ódio homofóbico}
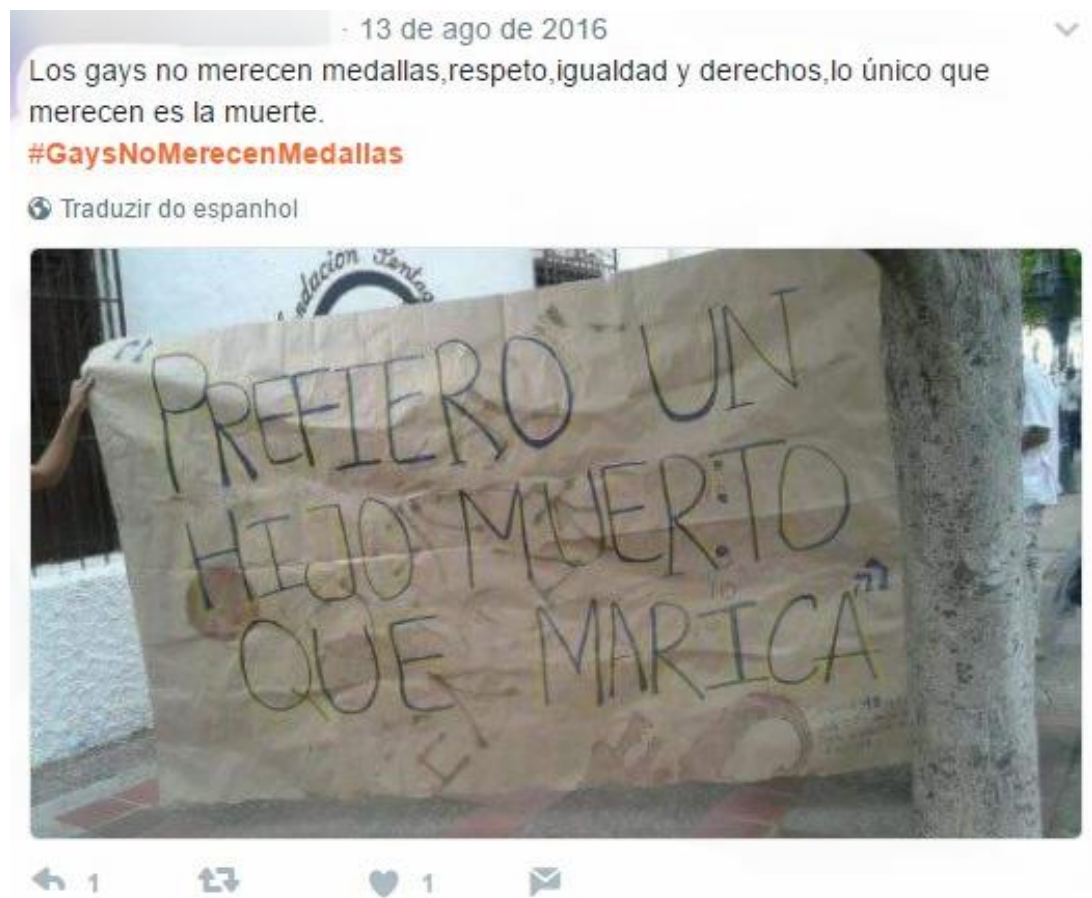

Fonte: Twitter, 2017

\footnotetext{
${ }^{8}$ Traduzido do espanhol para o português: "los gays no merecen medallas, respeto, igualdad y derechos, lo único que merecen es la muerte".

9 Traduzido do espanhol para o português: "prefiero um hijo muerto que marica".
} 
Essa segunda postagem é ainda mais agressiva, no sentido de que incita os demais usuários da plataforma não somente à discriminação, mas também à violência física, condenando os LGBTs à morte - trata-se de um caso de discurso de ódio. A frase do cartaz tem construção de sentido paralela às frases "melhor ter um filho drogado do que gay" ou "melhor ter um filho criminoso do que gay", com versões muito semelhantes no universo hispano-americano ${ }^{10}$, transmitindo justamente a ideia da homossexualidade como crime e comportamento de alta reprovabilidade social ("degenerescência"). No cartaz, contudo, a frase vai além, reforçando a ideia de que a vergonha da homossexualidade do filho é tão grande para família que os pais preferirão a morte do filho à sua própria existência enquanto gay. Para fazer referência à homossexualidade masculina utiliza a palavra maricas, de cunho pejorativo.

Tal qual a postagem constante da Figura 1, o tuíte apoia-se na ideologia do heterossexismo e dialoga com suas versões mais radicais, difundidas sobretudo em países onde a perseguição aos LGBTs é política de Estado. A visão da lésbica, do gay, do transexual, como inimigos do Estado é, entretanto, frequente mesmo em locais onde ser LGBT não é crime, como no Brasil e em outros países da América Latina.

Deste modo, pode-se concluir que postagens desse tipo são exemplificativas de práticas sociais que seguem reproduzindo uma ordem social de exclusão e, com isso, uma sociedade avessa à diversidade sexual. Representam, portanto, um problema, já que pautam ações futuras, contribuindo para a perpetuação de um ciclo histórico de discriminação (MATEUS; RESENDE, 2015). Nesse processo, servem de pontos focais para novas manifestações de ódio e, inclusive, para outras formas mais concretas de violência ${ }^{11}$.

\section{RESISTÊNCIA: ATOR SOCIAL E HUMOR COMO ESTRATÉGIA}

Retomando conceitos da escola da Análise Crítica do Discurso, podemos dizer que, ainda que as estruturas sociais pautem discursos os quais, por sua vez, moldam estruturas cognitivas em nível pessoal, iniciativas particulares do indivíduo, como ator social, podem resistir à reprodução da ordem instituída, negando-se, ao menos em nível consciente, a replicar ideologias hegemônicas. Essa resistência pode se dar, inclusive, de maneira articulada e em rede, com o objetivo de gerar contranarrativas aptas a ameaçar, de maneira crescente, a prevalência de ideologias hegemônicas em determinados espaços. Isso porque, da mesma forma que as estruturas sociais e o contexto discursivo influenciam ações individuais, estas ações impactam a ordem do discurso e as estruturas sociais, tendo o potencial de modificar práticas ao longo do tempo (MATEUS; RESENDE, 2015).

Nesse cenário, se por um lado o Twitter viabiliza a disseminação de discursos discriminatórios de forma organizada e articulada, ele também torna possível iniciativas de contradiscurso que visem a desestruturar redes de replicação de ideologias segregacionistas.

\footnotetext{
10 "Prefiero um hijo yonki [gíria para usuário de drogas] a uno maricón", "prefiero un hijo ladrón a uno homosexual", dentre outros resultados da busca "prefiero un hijo" no mecanismo de pesquisa do Google no México (escolhido tendo em vista a suposta nacionalidade do tuíte original da campanha \#GaysNoMerecenMedallas) realizada no dia 14 de julho de 2017. Disponível em: <https://www.google.com.mx/\#q=prefiero+un+hijo\&start=10>.

${ }^{11}$ Considerar se a rede de práticas é um problema, terceira etapa da metodologia de Fairclough (2012).
} 
No caso específico da campanha \#GaysNoMerecenMedallas, ao buscar pela hashtag no Twitter, percebemos rapidamente que a maior parte dos usuários que a compartilharam o fizeram com o intuito de recriminá-la por meio do uso de diferentes estratégias. Dentre elas, é possível destacar o uso do humor ${ }^{12}$ - sobretudo por meio de "memes" - para deslegitimar usuários que apoiam a ideia de que ser LGBT não é motivo de orgulho, expondo-os ao ridículo. Esse potencial uso do humor é destacado por Sørensen em suas reflexões sobre o conceito:

\begin{abstract}
A única coisa que toda forma de humor tem em comum é que inclui uma incongruência que faz com que ao menos parte da audiência se divirta. Além dessa característica básica, o humor é extremamente diverso [...] é uma forma de comunicar que não é intrinsecamente positiva nem negativa. De maneira semelhante a outras formas de comunicação, pode ser usado para fazer as pessoas felizes ou causar a elas dano, intencionalmente ou não. Algumas formas de humor reforçam o status quo, enquanto outras encorajam rebeliões e algumas têm efeitos mistos (SØRENSEN, 2014, p. 491-492, tradução nossa)
\end{abstract}

Desenvolvendo mais essa ideia, Sørensen (2014, p. 491-492) destaca que, ao contrário do que defendem muitos teóricos dos estudos do humor no sentido de que o humor é provavelmente inútil no contexto das lutas por mudanças sociais e políticas, poder e resistência não são unidimensionais, mantendo relações sutis ainda mais difíceis de serem mapeadas no caso dos discursos humorísticos. Assim, esse tipo de discurso poderia ser caracterizado como resistência em determinados casos, já que "resistência" não pressupõe, necessariamente, confronto violento, mas a capacidade de fazer frente às investidas do poder constituído, ainda que de maneiras mais sutis.

Desta forma, o humor, em virtude de seu grande poder como estratégia de resistência, é efetivo na capacidade de ressignificar termos, imagens e símbolos usualmente associados aos LGBTs de forma negativa para esvaziá-los de sentido, desarmando aqueles que ainda fazem uso deles para marginalizar as minorias sexuais.

Antes de passarmos à análise dos memes para verificar como foram empregados na finalidade mencionada anteriormente, mostra-se necessário contextualizar o seu uso na comunicação entre usuários de plataformas na internet.

Ana Cristina Paula Lima, em sua Tese de Doutorado defendida na Escola de Comunicações e Artes da Universidade de São Paulo em 2014, explica que o conceito de "meme" tem origem em termo cunhado na biologia, ligado à parte do gene que copia informações entre células, tendo sido posteriormente levado para a área da antropologia. Dawkins introduziu o termo para fazer referência ao equivalente comportamental do gene, "um novo replicador [...] uma unidade de transmissão cultural, ou uma unidade de imitação", dando como exemplos "melodias, ideias, 'slogans', modas do vestuário, maneiras de fazer potes ou de construir arcos" (1979, p. 214). No campo da comunicação digital, o termo adquiriu o sentido de "gene da cultura, que se perpetua através de seus replicadores, as pessoas ou usuários de redes digitais" (LIMA, 2014, p. 45). Os memes visuais "são desenhos, imagens ou qualquer manifestação visual-verbal replicados ou

\footnotetext{
12 Identificar estratégias para superar obstáculos, quarta etapa da metodologia de Fairclough (2012) que será o foco de análise das próximas seções do presente estudo.
} 
compartilhados com alterações em diversos contextos adaptados a finalidades particulares de comunicação interpessoal” (LIMA, 2014, p. 46), utilizados com a finalidade de tornar a comunicação mais efetiva, já que a imitação encurta o percurso entre a intenção do emissor, em seus atos de fala, e a sua interpretação, por parte dos receptores e eventuais replicadores do meme.

Já os memes de natureza cômica, mais especificamente, são dotados de aspectos reconhecidos pela maioria da audiência, possuindo "boa solução formal e semântica com apelo comunicativo e expressivo" (LIMA, 2014, p. 48), e estabelecendo diálogo com a cultura da internet. Conformam discurso digital típico, sendo amplamente difundidos em plataformas como o Twitter, o Facebook, o Whatsapp, o Instagram, dentre outras.

Vejamos como foram empregados na prática no contexto da campanha \#GaysNoMerecenMedallas no Twitter.

\section{ANÁLISE DO CORPUS}

A Figura 3 mostra tuíte com a mensagem "Se me atacá, eu vou atacá \#GaysNoMerecenMedallas" (Frase 3A) junto de imagem com uma placa de sinalização, possivelmente situada em estrada de região montanhosa (ou ao menos não urbanizada), com a representação gráfica de um animal interagindo com uma pessoa. Acima da placa, a frase "sai, hétero" (Frase 3B), em letras relativamente grandes, em branco com contorno em preto.

Figura 3 - Tuíte com meme "sai, hétero"

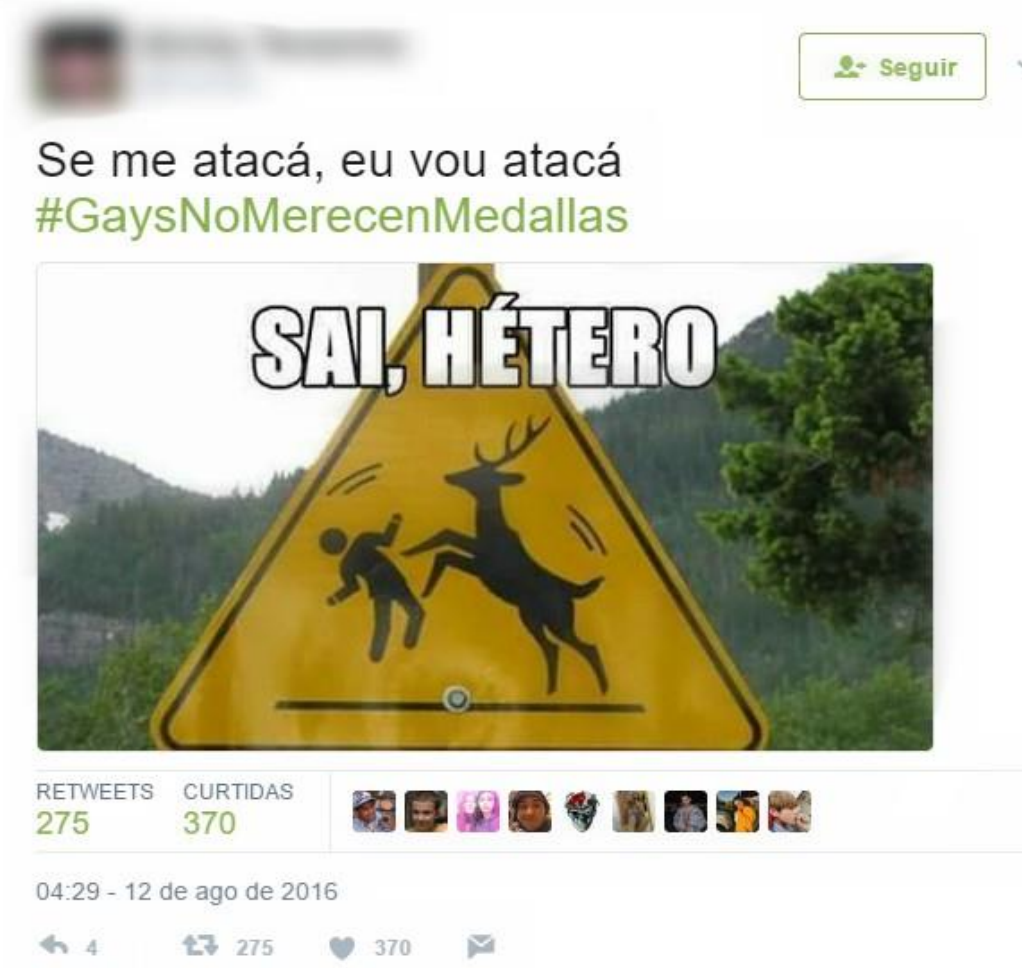

Fonte: Twitter, 2017 
Pela disposição das informações no tuíte, é possível inferir que a imagem ilustra, no concreto, o conteúdo da Frase 3A, bordão conhecido de Inês Brasil ${ }^{13}$, figura popular da cultura LGBT brasileira. As marcas de oralidade presentes na frase - a grafia "atacá" no lugar de "atacar" - reforçam as evidências de que o tuíte mantém relação de intertextualidade com o vídeo de Inês Brasil.

A frase, que por si só é um meme em se considerando a sua replicação ${ }^{14} \mathrm{em}$ diferentes contextos mantendo relação de sentido com o vídeo original de Inês Brasil (LIMA, 2014), transmite a ideia de que o enunciador, em sofrendo uma agressão (aqui inclusive no sentido verbal, não físico), responderá com nova agressão. Essa ideia contribui para a construção de sentido da Frase 3A, em que a hashtag \#GaysNoMerecenMedallas pode ser interpretada como uma agressão aos LGBTs, agressão essa respondida com um "ataque" do autor do tuíte, qual seja, a transmissão da imagem que se encontra abaixo da Frase 3A.

Na placa de sinalização, temos uma representação narrativa em um processo de ação transacional (NASCIMENTO et al., 2011) em que um animal (pela representação gráfica, um cervo) agride uma pessoa. A placa, em seu contexto original, tem sentido de comunicar a existência de animais silvestres nas proximidades, os quais representam risco à integridade física de seres humanos. No entanto, ao ser conjugada com a Frase 3B-e também a Frase 3A - adquire novo sentido, em torno da oposição homossexuais (nós) X heterossexuais (eles): o cervo representa o gay se desvencilhando do ataque de uma pessoa heterossexual (representada graficamente pelo ser humano).

Ao valer-se da figura do cervo - ou "veado" - para representar a agressão de um gay a uma pessoa heterossexual, o autor do tuíte reapropria-se da imagem do animal, historicamente associado de forma negativa, no Brasil, à figura do homossexual masculino, para demovê-lo de seu sentido pejorativo: ao representá-lo com grande destaque (o que podemos inferir pelo tamanho do cervo na representação gráfica e pela sua centralidade na ação ilustrada) e com aspecto de força, o veado é desassociado da ideia de fragilidade e passividade. Em outras palavras, o próprio gay (nós) é representado positivamente, por meio da associação à figura do cervo, como agente munido de força para rebater agressões feitas por não-LGBTs (eles).

O tuíte transmite forte mensagem - tanto aos LGBTs no sentido de que são fortes e devem reagir a agressões, quanto aos não-LGBTs no sentido de que devem esperar revides caso "ataquem" os LGBTs. Ao estimular a resistência ao discurso hegemônico de ataque a minorias sexuais, o tuíte constitui exemplo de como os indivíduos LGBTs, enquanto atores sociais (MELO, 2009), podem fazer frente à reprodução da ordem social constituída.

\footnotetext{
${ }^{13}$ Vídeo disponível em: <https://www.youtube.com/watch?v=sPVRytXk0YI>. Acesso em 18 de julho de 2017.

${ }^{14}$ Pesquisa realizada no dia 18 de julho de 2017 por meio da ferramenta de busca do Google revelou a existência de diversos memes com a frase. Conferir: $<$ https://www.google.com.br/search?q=se+me+ataca+eu+vo+ataca\&source=lnms\&tbm=isch\&sa=X\&ved $=0$ ahUKEwjroOC1hpPVAhUFIJAKHUrLB3oQ_AUICigB\&biw=1366\&bih=638\#tbm=isch\&q=memes+ se+me+ataca+eu+vou+ataca>.
} 
É importante destacar que o tuíte causa o riso ao quebrar a expectativa de significado da placa (avisar da existência de animais silvestres perigosos) e, em segundo nível, da representação da figura do gay como frágil. Nesse contexto, o riso tem o potencial de engajar maior número de LGBTs à mensagem, fazendo com que se difunda ainda mais no Twitter e torne-se mais visível também às pessoas externas a esse grupo.

A Figura 4 mostra tuíte com a mensagem "Sobre a tag \#GaysNoMerecenMedallas" (Frase 4A) junto da imagem, em representação gráfica, de um cervo filhote com a Branca de Neve, e da legenda "Xiu viado, fala menos!" (Frase 4B). Aqui a construção de sentido se dá, de maneira semelhante àquela observada na Figura 3, em torno da figura do cervo (ou veado) como forma de representação do homem gay. A diferença na grafia - de "veado" para "viado" - representa marca de oralidade.

\section{Figura 4 - Tuíte com meme "xiu viado"}

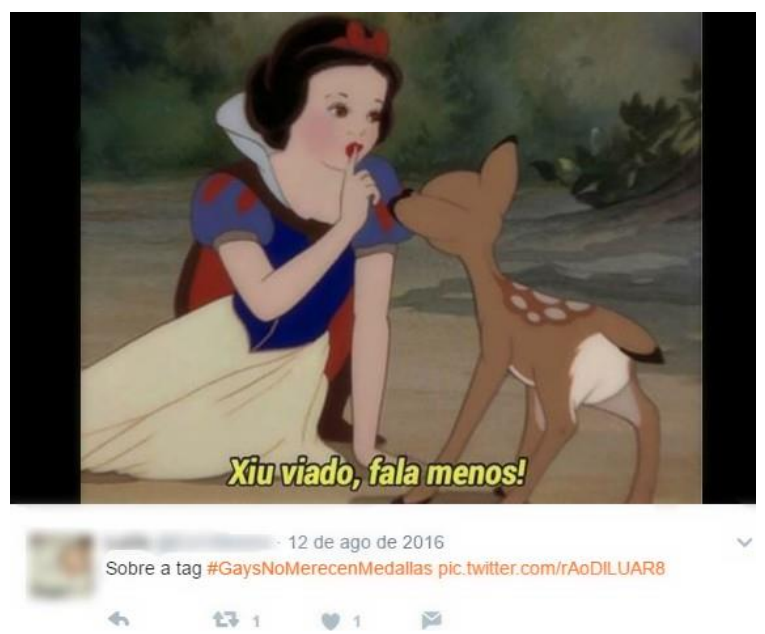

Fonte: Twitter, 2017

É preciso destacar, no entanto, que há uma diferença em relação à Figura 3: a expressão "xiu viado", usualmente empregada por membros da comunidade LGBT para mostrar discordância em relação a determinada ideia/opinião de uma pessoa (seja ela também da comunidade LGBT ou não), é empregada no contexto do tuíte para censurar o autor da hashtag \#GaysNoMerecenMedallas (e seus apoiadores), sugerindo o seu silenciamento.

Assim, na ilustração da Figura 4, o cervo representa aqueles que pensam que "gays não merecem medalhas" (ou que ser LGBT não é motivo de orgulho), enquanto a figura da Branca de Neve, em posição superior no eixo horizontal em relação ao cervo, representa alguém com maior autoridade (NASCIMENTO et al., 2011) para falar sobre o assunto (possivelmente os próprios LGBTs), censurando a manifestação de intolerância contida na hashtag. Ao não projetar os LGBTs na figura do cervo, o tuíte trabalha com ambiguidade: pode meramente indicar que os não-LGBTs que apoiam a hashtag devem ser censurados/confrontados por alguém, como pode, da mesma forma, desestruturar a oposição nós (LGBTs) X eles (não-LGBTs), indicando que os apoiadores podem igualmente fazer parte do endogrupo. Nesse segundo caso, estariam em fase ainda imatura 
(o que se pode inferir do caráter infantil do cervo) em que atacam a expressão da diversidade sexual para reprimir seus próprios desejos.

Mais uma vez, o riso é causado por quebras de expectativa entre o que Branca de Neve estava dizendo na animação homônima dos Estúdios Disney no momento retratado e a frase atribuída a ela na legenda que consta da imagem, bem como entre o termo que se espera atribuir a alguém que apoia a hashtag \#GaysNoMerecenMedallas e o uso (bem como a representação gráfica) da expressão "veado" - ou "viado", na versão da palavra com marcas de oralidade.

Também nesse caso, o tuíte introduz uma estratégia de resistência a discursos hegemônicos que os LGBTs, enquanto atores sociais integrantes de grupo subalternizado (MELO, 2009), podem adotar: intervir ao presenciar a disseminação de discursos silenciando-os.

A Figura 5 mostra tuíte que compartilha imagem do Pontífice da Igreja Católica e atual Chefe de Estado do Vaticano, Papa Francisco, acompanhado da legenda "mim poupe, se poupe, nos poupe" (Frase 5A) e a frase "sobre essa tag vergonhosa \#GaysNoMerecenMedallas" (Frase 5B).

\section{Figura 5 - Tuíte com meme "mim poupe"}

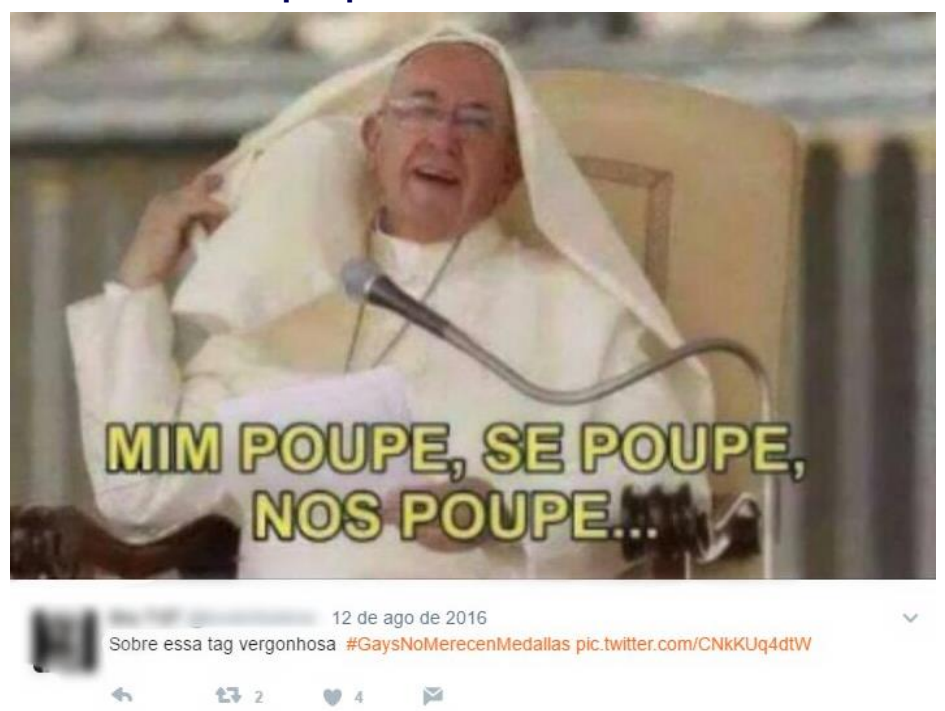

Fonte: Twitter, 2017

Nesse caso, a construção de sentido está intimamente relacionada à configuração da mão direita e do rosto do pontífice, que transmitem certo ar de superioridade, análogo à situação em que uma pessoa joga seus cabelos para trás e vira o rosto para não discutir com seu interlocutor. Essa ideia é confirmada pela legenda com a Frase 5A, uma versão mais longa e hiperbólica da expressão "me poupe", amplamente utilizada para marcar discordância em relação a uma opinião do interlocutor e indisposição em seguir debatendo o assunto da divergência. Contextualizando a imagem e a legenda à Frase 5B, temos que o autor do tuíte ("mim poupe") - e os LGBTs enquanto grupo ("nos poupe") - representado(s) na figura do papa, reprova(m) a hashtag \#GaysNoMerecenMedallas, negando-se a sequer estabelecer diálogo com pessoas que apoiam campanha para a qual 
não há justificativa válida. Essa mensagem é dirigida não apenas a quem já se posicionou favoravelmente à hashtag no Twitter, mas também a quem lê e concorda com ela: nesse caso, o enunciador emprega o contato visual do papa para requerer à pessoa que "se poupe", no sentido de manter-se calada e não passar vergonha.

O uso da imagem do pontífice em uma situação imprevista - muito provavelmente ele não tinha a intenção marcar discordância e indisposição no momento em que foi fotografado - tem efeito cômico. Esse efeito é ressaltado pelo uso irônico da imagem do papa, símbolo de uma instituição que historicamente condena a diversidade sexual, para transmitir uma mensagem diametralmente oposta àquela pregada pela Igreja Católica: ser LGBTs é motivo de orgulho. Há, ainda, o uso de aliteração, caracterizado pela repetição do fonema /p/ nas palavras "papa" (implícita à imagem) e "poupe", na legenda. O uso do pronome oblíquo tônico "mim" em "mim poupe" também contribui para o efeito cômico, ao quebrar a expectativa de observância da norma culta da língua, contemplada na expressão "me poupe".

Também nesse caso, o riso desempenha papel importante na transmissão da mensagem, a qual se torna mais visível ao utilizar a imagem cômica do papa de maneira irônica para repreender a disseminação da LGBTfobia no Twitter: além de atacar a hashtag \#GaysNoMerecenMedallas, o tuíte tece crítica à Igreja Católica, uma instituição poderosa que teve - e continua a ter - papel ativo no empreendimento de marginalização da diversidade sexual (OLIVA, 2015). A estratégia de resistência proposta no tuíte é, no entanto, diferente daquela observada na Figura 4: negar-se a estabelecer diálogo com quem adota discursos heterossexistas.

A Figura 6 mostra tuíte com imagem em que um homem, representando determinada delegação no contexto da abertura dos Jogos Olímpicos do Rio, mantém contato visual com a câmera enquanto tira seus óculos. No lugar onde deveria constar o nome da delegação, na placa que se encontra sobre a cabeça do homem, lê-se "Vale dos Homossexuais". Acima da imagem, há ainda a mensagem "\#GaysNoMerecenMedallas merecem medalhas sim, e respeito, não precisa aceitar, respeito resolve tudo. Bjs no coração." (Frase 6A).

\section{Figura 6 - Tuíte com meme "vale dos homossexuais"}

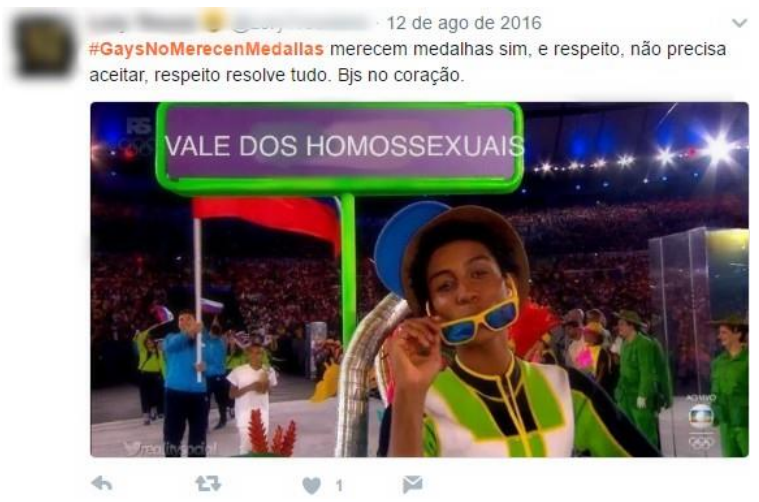

Fonte: Twitter, 2017 
A construção de sentido se dá pela intertextualidade entre a imagem e a ideia de "Vale dos Homossexuais", descrita em vídeo ${ }^{15}$ por uma pastora evangélica que afirma ter ido "várias vezes ao inferno". Pautando seu depoimento em Levítico 18, versículo $22^{16}$ e Romanos 1, versículos 26 a $32{ }^{17}$ da Bíblia, a pastora concebe o "Vale dos Homossexuais" como espaço de penitência de lésbicas e gays "no inferno". O vídeo repercutiu na internet, especialmente entre a comunidade LGBT, que se apropriou do termo "Vale dos Homossexuais", cunhado com o objetivo de depreciar os LGBTs ao rotulá-los de "pecadores", para ironizar o sentido atribuído pela pastora - e outros líderes religiosos e atribuir a ele uma conotação positiva.

É esse o caso da Figura 6, em que a expressão "Vale dos Homossexuais" é empregada de maneira positiva, para designar os homossexuais como uma delegação, em um contexto de celebração da diversidade, representada pelo homem que porta a placa da "nação LGBT". A atmosfera de descontração, inferida do contato visual amigável do homem com a câmera, contrasta com a pretensa seriedade do vídeo da pastora. Além disso, ao conjugar a imagem com o título "Vale dos Homossexuais" na placa e a Frase 6A, o autor do tuíte transmite a mensagem de que o homem (representativo dos LGBTs), ao baixar os óculos, mostrar seus olhos e manter contato visual com a câmera, revela sua identidade gay, mostra-se orgulhoso dela (pelo contexto dos holofotes ao fundo) e requer ao interlocutor, de maneira conciliatória, que respeite sua identidade.

A mensagem dialoga com a hashtag ao estabelecer que os LGBTs merecem não apenas medalhas (na competição esportiva), mas ainda respeito. Assim, a estratégia de resistência assinalada na Figura 6 sugere uma abordagem mais conciliatória junto àqueles que reproduzem, acriticamente, uma ordem social de exclusão dos LGBTs.

Nesse caso, o efeito cômico é causado justamente pela intertextualidade da imagem com o vídeo da pastora e sua tentativa de cunhar um novo termo para seguir empreendendo o projeto de marginalização social de LGBTs, o qual seria legitimado pela autoridade religiosa da Bíblia, na visão da pastora. O riso advém justamente do uso da expressão "Vale dos Homossexuais" para retratar uma "nação LGBT" orgulhosa e assertiva.

Também na Figura 7, a construção de sentido se dá pela relação que o tuíte estabelece com a Bíblia, retratada com destaque na imagem, onde se lê em letras grandes

15 Vídeo disponível em: <http://revistaladoa.com.br/2013/10/noticias/pastora-ex-lesbica-diz-que-foi-aoinferno-15-vezes-viu-vale-homossexuais>. Acesso em 18 jul. 2017.

${ }^{16}$ No vídeo a pastora faz referência ao versículo 21, mas cita o 22: "Com homem não te deitarás, como se fosse mulher; abominação é”. Bíblia Online, disponível em <https://www.bibliaonline.com.br/acf/lv/18>. Acesso em 18 jul. 2017.

17 “26. Por isso Deus os abandonou às paixões infames. Porque até as suas mulheres mudaram o uso natural, no contrário à natureza. 27. E, semelhantemente, também os homens, deixando o uso natural da mulher, se inflamaram em sua sensualidade uns para com os outros, homens com homens, cometendo torpeza e recebendo em si mesmos a recompensa que convinha ao seu erro. 28. E, como eles não se importaram de ter conhecimento de Deus, assim Deus os entregou a um sentimento perverso, para fazerem coisas que não convêm. 29. Estando cheios de toda a iniquidade, fornicação, malícia, avareza, maldade; cheios de inveja, homicídio, contenda, engano, malignidade. 30. Sendo murmuradores, detratores, aborrecedores de Deus, injuriadores, soberbos, presunçosos, inventores de males, desobedientes aos pais e às mães. 31. Néscios, infiéis nos contratos, sem afeição natural, irreconciliáveis, sem misericórdia. 32. Os quais, conhecendo o juízo de Deus (que são dignos de morte os que tais coisas praticam), não somente as fazem, mas também consentem aos que as fazem". 
"Pode sapatão Pode viado", frase sobreposta ao texto do livro. O autor do tuíte ainda escreve "Se tá na Bíblia, é verdade \#GaysNoMerecenMedallas" (Frase 7A). Aqui, a mensagem transmitida é uma crítica dirigida àqueles que consideram que ser LGBT é condenável em virtude de uma pretensa interdição, nesse sentido, pela Bíblia. A crítica tem dois níveis: no primeiro, ironiza aqueles que entendem que o livro religioso veda a homossexualidade com todas as letras; no segundo, aqueles que usam o livro religioso de base para avaliar como certo ou errado determinado comportamento social.

Figura 7 - Tuíte com meme "pode sapatão, pode viado"

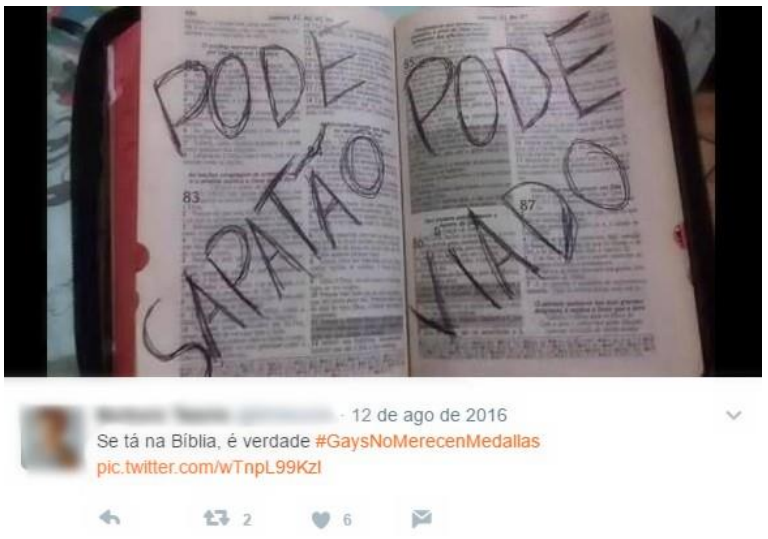

Fonte: Twitter, 2017

O tuíte identifica a discriminação a LGBTs em contextos religiosos (mais especificamente cristão) como origem da opinião daqueles que apoiam a hashtag, propondo ironicamente a inserção da permissão à identidade lésbica ("sapatão") e gay ("viado") na Bíblia para solucionar o problema da interdição religiosa. Essa inserção transmite mensagem de ordem simbólica poderosa, passível de causar desconforto em religiosos em geral: escrever agressivamente sobre um texto sagrado comunica a ideia de que não importa o que digam as religiões, ser LGBT é permitido e ponto final.

O efeito cômico é causado pela solução esdrúxula - e claramente irônica - proposta pelo autor do tuíte ao apoio à hashtag \#GaysNoMerecenMedallas: ao invés de educar aqueles avessos à manifestação da diversidade, mais fácil seria modificar a Bíblia para que ela diga claramente que ser LGBT é permitido. O efeito é reforçado pelo uso das palavras "sapatão" e "veado" (mais uma vez em sua versão com marcas de oralidade, "viado"), usualmente empregados com caráter pejorativo para fazer referência a lésbicas e gays em contextos informais, em frases objetivas, o que contrasta com a linguagem prolixa e anacrônica de textos religiosos. Há, ainda, a saliência da frase "Pode sapatão Pode viado", que aparece com grande destaque na imagem em virtude de seu tamanho desproporcionalmente grande e colocação em primeiro plano, como se tivesse autoridade superior ao conteúdo original da Bíblia.

Neste tuíte, a estratégia de resistência articulada indica uma postura mais assertiva em relação a discursos de caráter religioso avessos à diversidade sexual, sugerindo ser essencial elevar o tom da resistência no espaço público para o discurso religioso deixe de ter um papel preponderante na estruturação da ordem social. 
Nesta seção são sistematizadas as conclusões do trabalho e é desenvolvida reflexão crítica sobre a análise conduzida no estudo, última etapa da metodologia de Fairclough (2012).

Situando os tuítes constantes das Figuras 3 a 7 em cenário mais amplo de reprodução da ordem social heterossexista por meio do discurso, verifica-se que eles representam uma forma de resistência ao contestarem a ideia de que ser LGBT não é motivo de orgulho. Para tanto, utilizam-se de diferentes mecanismos linguísticos, estéticos e simbólicos para a reapropriação de termos e imagens usualmente empregados para fazer referência aos LGBTs de forma pejorativa. Nesse processo, contestam não apenas aqueles que apoiam a hashtag \#GaysNoMerecenMedallas, mas também instâncias de poder como a Igreja Católica e igrejas de denominação evangélica que seguem contribuindo para a marginalização dos LGBTs. Os autores dos tuítes desempenham, dessa forma, o papel de atores sociais do modo como concebido pela escola da Análise Crítica do Discurso: resistem à reprodução da ordem instituída, desenvolvendo contranarrativas aptas a ameaçar a prevalência do heterossexismo - ao menos no Twitter.

Além de repertório compartilhado - a exemplo do uso da palavra/imagem "viado" e de referências religiosas, como a Bíblia e o papa -, os tuítes têm em comum o uso de memes de natureza cômica, o que contribui para a difusão e visibilidade de seus aspectos formais e semânticos em virtude de seu grande apelo expressivo e eficiência comunicativa na internet. Além de projetar e reforçar a visão de mundo compartilhada pelos LGBTs no que diz respeito à diversidade sexual, os memes de natureza cômica chamam a atenção de pessoas externas ao grupo e deslegitimam o discurso hegemônico de pessoas/instituições poderosas, expondo-os ao ridículo. Apresentam-se, assim, como alternativa ao discurso dominante.

Cabe ressaltar, nesse contexto, o papel de plataformas digitais como o Twitter: ao mesmo tempo em que intensificaram a difusão de discursos hegemônicos, ampliaram o acesso ao discurso, por parte de integrantes de grupos minoritários. Esse fato tem implicações importantes ao considerarmos as dificuldades de articulação de iniciativas de contradiscurso em contextos pré-plataformas - e mais ainda em contextos pré-internet. Pode-se dizer, portanto, que essa relativa democratização do acesso ao discurso - ainda que longe do ideal, em se considerando aspectos materiais que seguem mantendo o acesso à internet assimétrico entre determinados grupos sociais - reduziu o controle dos grupos hegemônicos sobre os discursos em matéria de sexualidade.

No caso concreto, a estratégia pareceu efetiva ao considerarmos que a grande maioria dos tuítes que compartilharam a hashtag \#GaysNoMerecenMedallas o fizeram para atacá-la, inclusive por meio do uso de memes ${ }^{18}$. Além de mobilizar um grande número de usuários pró-LGBT, a reação contra a hashtag resultou no pronunciamento público de Daniel Bisogno - apresentador mexicano que teria sido responsável pelo início da campanha \#GaysNoMerecenMedallas. Bisogno afirmou ter sido vítima de phishing $^{19}$,

\footnotetext{
18 A busca por tuítes que apoiaram o uso da hashtag relevou essa grande desproporção. Conferir: <https://twitter.com/hashtag/GaysNoMerecenMedallas?src=hash>. Acesso em 1 de julho de 2017.

${ }^{19}$ Coleta de informações e usurpação de identidade na internet por meio de sites e links falsos.
} 
não sendo responsável pelo tuíte que deu início à hashtag. O apresentador disse ainda que iria tomar as medidas judiciais cabíveis contra o responsável (LÓPEZ, 2016).

Em síntese, a análise dos tuítes e o desenvolvimento da campanha \#GaysNoMerecenMedallas conduzem à conclusão de que o uso de memes funcionaram como estratégia de resistência a discursos heterossexistas, gerando o engajamento em rede de LGBTs - ao compartilhar códigos comuns a membros do grupo - e a simpatia de potenciais aliados à causa, deslegitimando o discurso discriminatório produzido por usuários do Twitter e, indiretamente, por instâncias de poder como a Igreja Católica e igrejas de denominação evangélica.

É importante ressaltar, por fim, que a estratégia empregada no caso em análise é muito similar à reação em rede à criação da hashtag \#HeterosexualPrideDay ("Dia do Orgulho Heterossexual", em português) no Twitter (BELAM, 2017), amplamente compartilhada no final de junho de 2017 como forma de censurar a celebração do Dia do Orgulho LGBT. De maneira semelhante às reações à hashtag \#GaysNoMerecenMedallas, a nova campanha LGBTfóbica mobilizou uma reação orgânica de resistência que fez uso do humor, o que sugere que tal estratégia não é exclusividade do contexto brasileiro.

\section{REFERÊNCIAS}

AVENDAÑO, T. C. Rio 2016 se transforma na Olimpíada mais gay da história, 12 de agosto de 2016, São Paulo. Disponível em: <http://brasil.elpais.com/brasil/2016/08/09/deportes/1470774769_409560.html>. Acesso em: 5 jul. 2017. BELAM, M. \#HeterosexualPrideDay backfires as LGBT users subvert it on Twitter. The Guardian, $30 \mathrm{de}$ junho de 2017. Disponível em: <https://www.theguardian.com/world/2017/jun/30/heterosexualpridedaybackfires-lgbt-users-subvert-twitter?CMP=fb_gu>. Acesso em: 19 jul. 2017.

BOLÍVAR, A. Análisis del discurso y compromiso social. Akademos, v. 5, n. 1, p. 7-31, 2003.

BORILLO, D. Homofobia - história e crítica de um preconceito. Belo Horizonte: Autêntica, 2010.

BRASIL. Secretaria de Direitos Humanos da Presidência da República. Relatório sobre violência homofóbica no Brasil: ano de 2012. Brasília, 2013. p. 18. Disponível em:

<http://www.sdh.gov.br/assuntos/lgbt/pdf/relatorio-violencia-homofobica-ano-2012>. Acesso em: 5 jul. 2017.

BUTLER, J. Excitable Speech - A Politics of the Performative. London: Routledge, 1997.

CARRARA, S.; AGUIÃO, S.; LOPES, P. V. L.; TOTA, M. Retratos da Política LGBT no Estado do Rio de Janeiro. Rio de Janeiro: CEPESC, 2017. Disponível em:

<http://www.clam.org.br/uploads/arquivo/RetratosDaPoliticaLGBT_RJ_Miolo_170526.pdf>. Acesso em: 5 jul. 2017.

DAWKINS, R. O gene egoísta. São Paulo: Edusp, 1979.

FAIRCLOUGH, N. Análise crítica do discurso como método em pesquisa social científica. Linha d'Água, v. 2, n. 25, p. 307-329, 2012.

GUATHIER, J. Arco-íris de sangue. Correio*, 24 de janeiro de 2017, Salvador. Disponível em: <https://grupogaydabahia.files.wordpress.com/2017/01/2-capa-correio-materia-2017.pdf>. Acesso em: 5 jul. 2017.

LIMA, A. C. P. V!sual, Coloquial,Virtu@al: o uso da expressão gráfica na conversação em redes sociais. 2014. Tese (Doutorado em Ciências da Comunicação) - Escola de Comunicação e Artes, Universidade de São Paulo, São Paulo, 2014.

LÓPEZ, A. G. El Trending Topic más homófobo de Río 2016: \#Gaysnomerecenmedallas. 20 minutos, 13 de agosto de 2016. Disponível em: < http://www.20minutos.es/noticia/2816951/0/twitter-comentarioshomofobos-atletas-medallistas-olimpicos/?utm_source=twitterfeed\&utm_medium=twitter $>$. Acesso em: 13 jul. 2017.

MATEUS, E.; RESENDE, V. M. O sistema posição-prática como categoria epistemológica: contribuições para a análise de discurso crítica. Alfa - Revista de Linguística, v. 59, n. 3, p. 445-469, 2015.

OLIVA, Thiago Dias. Memes de natureza cômica como estratégia de resistência a discursos hegemônicos: análise das reações à campanha \#gaysnomerecenmedallas no twitter. Linguagem em (Dis)curso - LemD, Tubarão, SC, v. 18, n. 3, p. 583-601, set./dez. 2018. 
MELO, I. F. Análise do discurso e análise crítica do discurso: desdobramentos e intersecções. Letra Magna Revista Eletrônica Científica em Língua Portuguesa, Linguística e Literatura, v. 5, n. 11, 2009.

MOTT, L.; MICHELS, E. GRUPO GAY DA BAHIA. Relatório 2016 - Assassinato de LGBT no Brasil. Disponível em: <https://homofobiamata.files.wordpress.com/2017/01/relatc3b3rio-2016-ps.pdf>. Acesso em: 5 jul. 2017.

NASCIMENTO, R. G.; BEZERRA, F. A. S.; HEBERLE, V. M. Multiletramentos: iniciação à análise de imagens. Linguagem \& Ensino, v. 14, n. 2, p. 529-552, 2011.

OLIVA, T. D. Minorias sexuais e os limites da liberdade de expressão - o discurso de ódio e a segregação social dos indivíduos LGBT no Brasil. Curitiba: Juruá, 2015.

SØRENSEN, M. J. Humorous Political Stunts: Nonviolent Public Challenges to Power. Tese (Doutorado em Filosofia) - Universidade de Wollongong, Austrália, 2014.

VAN DIJK, T. A. Discurso e poder. Tradução de Judith Hoffnagel et al. São Paulo: Ed. Contexto, 2015.

\section{Recebido em: 29/09/17. Aprovado em: 14/06/18.}

Title: Comic memes as resistance strategy to counter hegemonic discourses: an analysis of the reactions to the hashtag \#GaysNoMerecenMedallas on Twitter

Author: Thiago Dias Oliva

Abstract: In August 2016, during the Rio de Janeiro Olympic Games, the hashtag \#GaysNoMerecenMedallas (Gays do not deserve medals) became a trending topic on Twitter. This article aims to study the use of humor as strategy for giving new meaning to words, images and symbols which have been historically employed in the social representation of LGBT people in a negative way. It aims to show how that strategy may be effective as means for countering online attacks against this social group, undermining the harm potential of these attacks by turning them into something laughable. More specifically, this article analyzes five memes which were posted during the hashtag campaign \#GaysNoMerecenMedallas, attempting to challenge the hashtag. Theoretically, it relies on the Critical Discourse Analysis' concept of social actor, on Teun van Dijk's concept of power and hegemony (2015), as well as on the criteria developed by Nascimento, Bezerra and Heberle (2011) for studying multimodal discourses as theoretical reference frameworks. The methodology follows the path established by Fairclough (2012).

Keywords: LGBT. Social actor. Memes. Humor. Resistance.

Título: Memes de naturaleza cómica como estrategia de resistencia a discursos hegemónicos: análisis de las reacciones a campaña \#gaysnomerecenmedallas en twitter

Autor: Thiago Dias Oliva

Resumen: En agosto de 2016, en medio a los Juegos Olímpicos de Rio de Janeiro, la hashtag \#GaysNoMerecenMedallas se tornó trending topic de Twitter. Este trabajo propone el análisis del uso de humor como estrategia para resignificar términos, imágenes y símbolos históricamente empleados en la representación social negativa de LGBT para mostrar como la estrategia puede ser efectiva para desarticular ataques a ese grupo social en internet, vaciándolos de sentido por medio de la risa. El artículo propone, como objetivo específico, el análisis de cinco memes que fueron posteados en medio a campaña \#GaysNoMerecenMedallas, atacando la hashtag. Teóricamente, se despegan las nociones de actor social del Análisis Crítico del Discurso, de poder y hegemonía en Teun van Dijk (2015), así como los criterios para el estudio de discursos multimodales presentes en Nascimento, Bezerra y Heberle (2011). La metodología sigue el camino establecido por Fairclough (2012).

Palabras clave: LGBT. Actor social. Memes. Humor. Resistencia.

Este texto está licenciado com uma Licença Creative Commons Atribuição 4.0 Internacional.

OLIVA, Thiago Dias. Memes de natureza cômica como estratégia de resistência a discursos hegemônicos: análise das reações à campanha \#gaysnomerecenmedallas no twitter. Linguagem em (Dis)curso - LemD, Tubarão, SC, v. 18, n. 3, p. 583-601, set./dez. 2018. 